\title{
FLUID REGIMES RELATED TO THE FORMATION OF LODE-GOLD DEPOSITS IN THE RIO ITAPICURU GREENSTONE BELT, BAHIA: A FLUID INCLUSION REVIEW
}

\author{
ROBERTO PEREZ XAVIER ${ }^{1}$ AND CARLOS EDUARDO SILVA COELHO ${ }^{2}$
}

\begin{abstract}
The shear zone-hosted gold deposits of the Rio Itapicuru Greenstone Belt, northeastern Brazil, are located in its southern and northern sectors, the former including Fazenda Brasileiro Mine and Fazenda Canto deposit and the latter Fazenda Maria Preta, Mari and Ambrósio deposits. Fluid inclusion studies by microthermometry and laser Raman microspectroscopy in mineralized quartz veins of these deposits reveal two main populations of inclusions: primary, $\mathrm{CO}_{2}-\left( \pm \mathrm{CH}_{4} \pm \mathrm{N}_{2}\right)$ inclusions (type I), and low salinity $\left(<6 \mathrm{wt} \% \mathrm{NaCleq}\right.$.) $\mathrm{H}_{2} \mathrm{O}$ - $\mathrm{CO}_{2}-\left( \pm \mathrm{CH}_{4} \pm \mathrm{N}_{2}\right)$ inclusions (type II), representing fluid regimes, which were active during the gold mineralizing events. Both types of ore fluids are interpreted as part of a deep hydrothermal system, in which the fluid components may have been derived by devolatilization reactions during regional metamorphism and/or from mantle-magmatic sources (e.g. $\left.\mathrm{CO}_{2}, \mathrm{H}_{2} \mathrm{~S}\right)$. The nature of the $\mathrm{CO}_{2}$-rich fluid regime, atypical in mesothermal lode-gold deposits, still remains an open question. Gold deposition from bisulfide complexes took place at different crustal levels, at temperatures varying from 280 up to $500^{\circ} \mathrm{C}$, and pressures from 1 up to $4.4 \mathrm{~kb}$, probably closely linked with and dependent upon redox changes that accompanied the interaction of the fluids with mafic and carbonaceous host rocks.
\end{abstract}

Keywords:

INTRODUCTION The Paleoproterozoic sector $(2.2-1.8 \mathrm{Ga})$ of the northeastern margin of the São Francisco Craton, State of Bahia, consists of a highly folded sequence of mafic volcanic rocks, andesiticdacitic lavas/pyroclastic rocks and volcanically-derived turbidites, probably developed in a back-arc environment. The volcanosedimentary sequence surrounds granite-gneiss domes and is metamorphosed in the greenschist and lower amphibolite facies (Kishida and Riccio 1980, Silva 1987) (Fig. 1).

The Rio Itapicuru greenstone belt (RIGB) contains a series of small- to medium-sized lode-gold deposits located in its southern and northern sectors, the former including Fazenda Brasileiro Mine and Fazenda Canto deposit and the latter Fazenda Maria Preta, Mari and Ambrósio deposits. These deposits are confined, respectively, to E-W and N-S regional-scale, brittle-ductile shear zones (Fig 1). The leading gold producer is the Fazenda Brasileiro Mine, Brazil's second most important mine, having produced 48.8 tonnes of gold to 1999. Other deposits in the northern sector, with operations presently suspended, have contributed with less than $25 \%$ of the total production.

This review paper attempts to reconstruct the nature and evolution of the ore-bearing fluids involved in the formation of the RIGB gold deposits, as well as to constrain the physico-chemical parameters which controlled gold deposition, based mainly on a compilation of fluid inclusion data available in the general literature and in unpublished M.Sc. dissertations and Ph.D. theses.

GEOLOGICAL SETTING OF THE GOLD DEPOSITS Southern Sector The Fazenda Brasileiro (FB) Mine and the Fazenda Canto (FC) deposit are the most important gold deposits in this sector, both being confined to a 8-km long, E-W shear zone named Weber Belt (Fig. 1). The major orebodies at FB consist of sulfide-rich, quartz-carbonate-albite vein systems hosted by a chlorite-magnetite schist, possibly a hydrothermally-altered mafic intrusion (Teixeira $e t$ al. 1990). The alteration assemblage generally present in the vicinity of the gold-bearing vein systems includes quartz + albite + carbonate \pm biotite \pm sphene + ilmenite + rutile + sulfides (mainly arsenopyrite, pyrrhotite, minor pyrite) (Marimon et al. 1986, Vieira et al. 1998).

At FC, the gold mineralization occurs mainly in foliation-parallel quartz-carbonate-albite veins and veinlets hosted by a sequence of highly deformed carbonaceous metavolcaniclastics and metapelites (Pereira Silva 1998). Hydrothermal alteration is characterized by the widespread formation of carbonate, chlorite, white mica, and biotite. In the proximity of gold-bearing quartz veins, arsenopyrite and pyrite become the most abundant sulfide phases in the host carbonaceous sediments.

In both deposits, gold occurs in its native state finely disseminated in the vein quartz, closely associated with sulfides, particularly arsenopyrite, white mica and chlorite, or along microfractures.

Northern Sector In this sector of the RIGB, N-S brittle-ductile shear zones are the major sites for gold deposits, particularly at Fazen- da Maria Preta (FMP) and Mari (MR) (Fig. 1). The orebodies in the former occur as shear veins hosted by highly deformed carbonaceous turbidites and quartz-ankerite breccias, whereas in the latter they are mainly associated with quartz veins in mafic subvolcanic intrusives (Xavier 1991, Coelho 1994, Barrueto 1996). Hydrothermal alteration, represented by carbonatization and sericitization, is remarkably widespread throughout the shear zones.

Native gold appears in both deposits as free grains finely disseminated or along microfractures in the quartz veins/breccias or closely associated with pyrite, arsenopyrite, pyrrhotite, sphalerite, and Fe-chlorite in the vein wallrocks or in slivers of the wallrocks in the veins.

The Ambrósio deposit is located at the contact of highly deformed volcanics and clastic-chemical sedimentary rocks, tightly squeezed between two syntectonic granitic batholiths (Pedra Alta and Ambrósio Domes), and metamorphosed to amphibolite facies (Pires 1996) (Fig. 1). The gold mineralization is closely associated with quartz veinlets containing disseminations of iron sulfides (arsenopyrite, pyrrhotite and pyrite), biotite, plagioclase and muscovite.

The gold-bearing veins, breccia and stockwork systems are interpreted to have been emplaced during syn- to late stages of deformation within the shear zones $\left(\mathrm{D}_{2}\right.$ event of Alves da Silva et al. 1993).

\section{FLUID INCLUSION CHARACTERISTICS IN THE GOLD}

DEPOSITS Fluid inclusions (FI) in gold-bearing vein quartz of all the investigated gold deposits in the southern and northern sectors of the RIGB can be broadly grouped into two major categories: type-I monophase carbonic inclusions and type-II aqueous-carbonic inclusions. Late aqueous inclusions will not be discussed here since they are post-mineralization. The nature and the compositional aspects of types I and II inclusions and their microthermometry data are summarized in Table 1.

Southern Sector At FB, fluid inclusion studies were performed on two sets of mineralized veins (Coelho 1994), parallel and discordant to the mylonitic foliation, locally consisting of a dense network of small diffuse veins. In both vein sets, quartz is strongly recrystallized, with development of porphyroclasts and pervasive formation of sub-grains.

Only monophase carbonic inclusions (type I) of primary nature are observed in quartz porphyroclasts, and have been interpreted as related to the formation of the auriferous veins. These inclusions are also observed in recrystallized quartz and along their boundaries, indicating that the circulation of such fluids remained active during the recrystallization event. Microthermometric and Laser Raman Microspectroscopy (LRM) data for these inclusions revealed a composition dominated by $\mathrm{CO}_{2}$, with a few mole $\%$ of $\mathrm{CH}_{4}$ and $\mathrm{N}_{2}$, (Table 1). The monophase inclusions related to the recrystallized quartz grains display a more variable volatile composition than those within porphyroclasts. On the other hand, aqueous-carbonic inclusions

1 - Instituto de Geociências, UNICAMP, Caixa Postal 6152, 13.083-970 - Campinas-SP, Brasil; e-mail: xavier@ige.unicamp.br

2 - Research Group on Metalogenesis, Centro de Pesquisa em Geofísica e Geologia and Curso de Pós-Graduação em Geologia, Instituto de Geociências, Universidade Federal da Bahia. Rua Caetano Moura, 123 40210-340 - Federação, Salvador-Bahia, Brasil.; e-mail: ccoelho@cpgg.ufba.br 

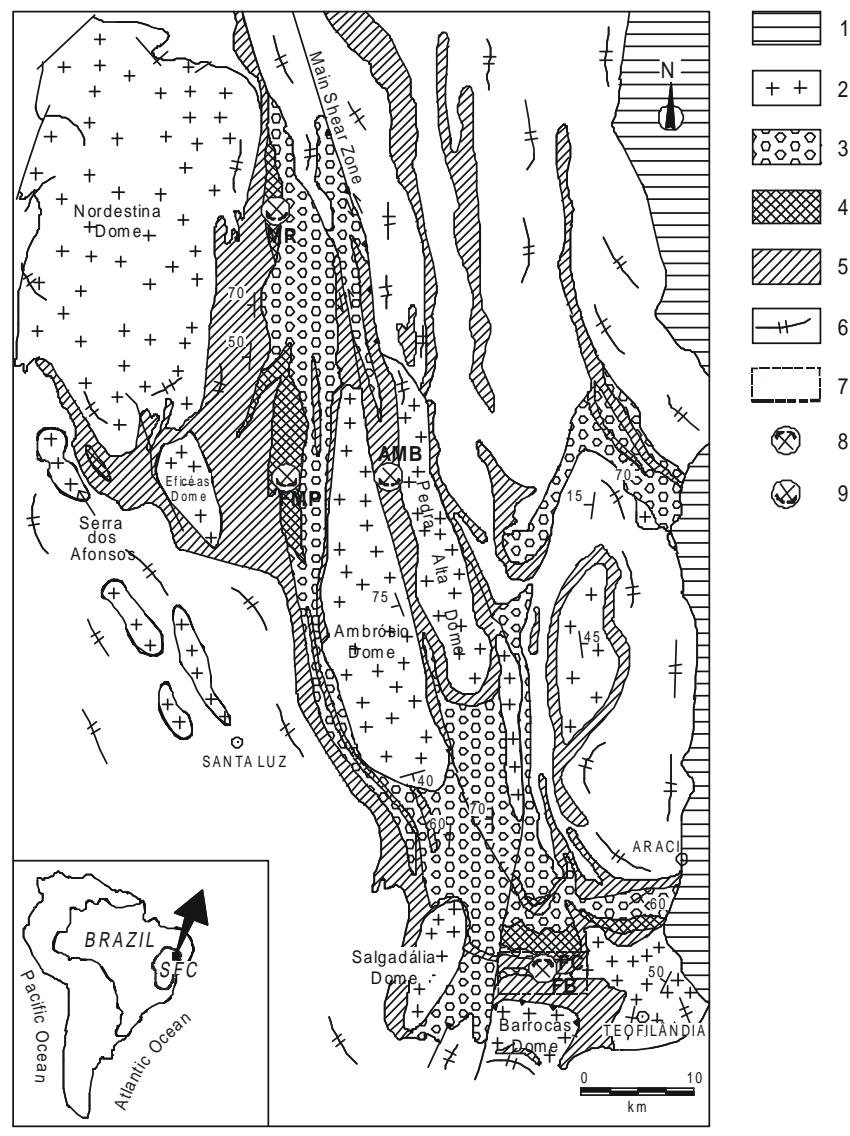

Figure 1-Simplified regional geologic map of the Rio Itapicuru Greenstone Belt with the location of the Fazenda Brasileiro (FB) Mine and the Fazenda Canto (FC), Fazenda Maria Preta (FMP), Mari (MR) and Ambrósio (AMB) gold deposits. $1=$ Cretaceous sediments (Tucano basin); $2=$ granites; $3=$ Volcaniclastic sedimentary unit; $4=$ Intermediate to felsic volcanic unit; $5=$ Mafic volcanic unit; $6=$ TTG basement; $7=$ Weber gold district $; 8=$ active gold mine; 9 = inactive gold mine. Modified from Alves da Silva et al. (1993).

(type II) occur only within recrystallized quartz and along their boundaries, suggesting a close relationship with the recrystallization event. Based on microthermometry and LRM data, these inclusion fluids are defined as low-salinity (up to $3.5 \mathrm{wt} \% \mathrm{NaCleq}$.), aqueous solutions, with a $\mathrm{CO}_{2}$-rich volatile content but with higher amounts of $\mathrm{CH}_{4} \pm \mathrm{N}_{2}$ than those observed in type I (Table 1). Their total homogenization temperature (Tht) occurred to the liquid or to the vapor phase, and cluster between $160^{\circ}$ and $290^{\circ} \mathrm{C}$ (Table 1). Primary to late recrystallization, monophase and two-phase inclusions occur along microcracks that crosscut both porphyroclasts and recrystallized quartz grains. Their microthermometry and LRM data reveal that these fluids consist of a mixture of $\mathrm{CH}_{ \pm} \pm \mathrm{N}_{2}$.

The auriferous veins of the FC deposit also display a high degree of quartz recovery with sub-grains largely dominated by monophase $\mathrm{CO}_{2} \pm \mathrm{CH}_{4} \pm \mathrm{N}_{2}$ inclusions (type I), as large intragranular swarms and planar arrays (Pereira Silva 1998). Primary-like groups of type-II inclusions consist of low salinity $(<5 \mathrm{wt} \%$ NaCleq. $), \mathrm{H}_{2} \mathrm{O}-(9-17$ mol\%) $\mathrm{CO}_{2}$ fluids, with $<5 \mathrm{~mol} \% \mathrm{CH}_{4}+\mathrm{N}_{2}$, and are observed only in a few veins. Total homogenization temperatures for this type of inclusions are not recorded due to decrepitation.

Northern Sector Fluid inclusion studies at the FMP and MR deposits were carried out mainly on gold-bearing ankerite-albitesulfide-quartz veins, parallel and discordant to the mylonitic foliation, and that are hosted by carbonaceous turbidites (e.g. the Antas orebodies, Xavier 1991) and mafic intrusive rock (e.g. the C1A orebody, Barrueto 1996), respectively. Only one amphibolite-hosted auriferous vein was investigated at the amphibolite facies AMB deposit.

Monophase carbonic inclusions of type I are by far the dominant
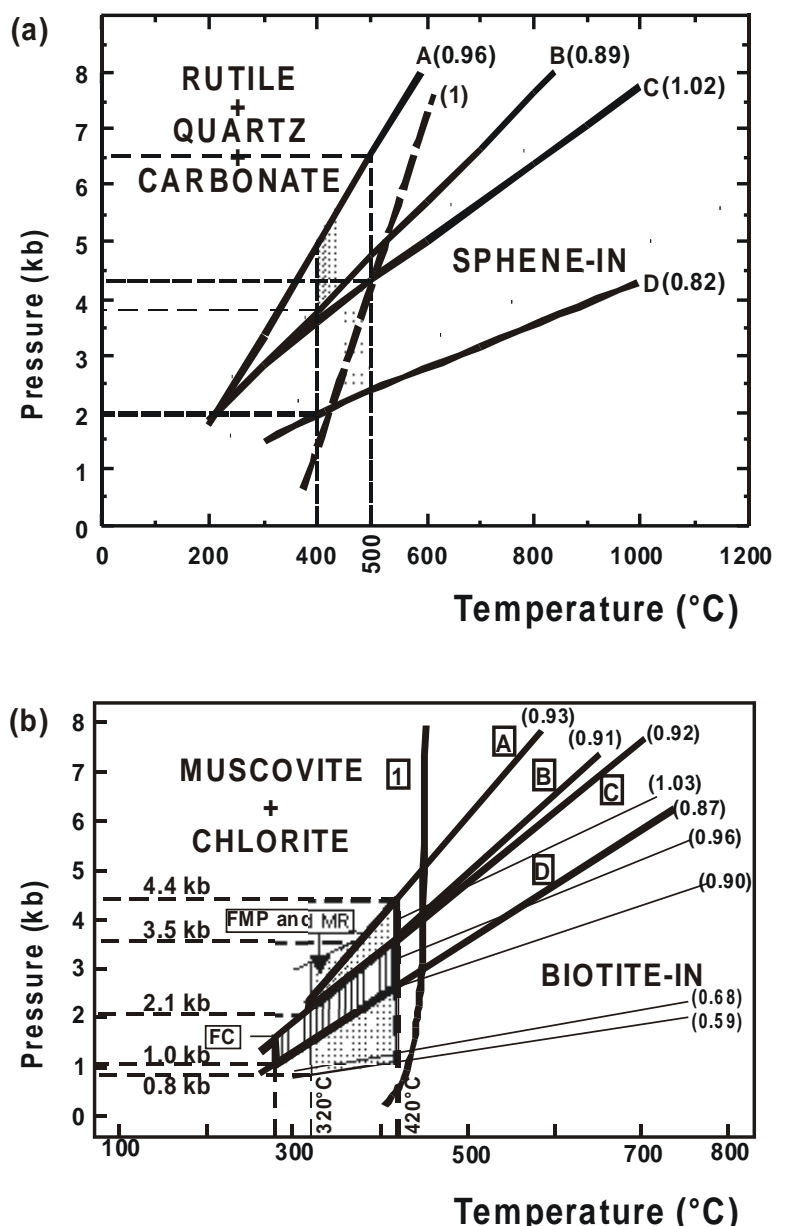

Figure $2-P-T$ conditions for the formation of the lode-gold deposits of the RIGB. (a) FB Mine. Curve 1 marks the appearance of sphene. Bulk-density isochores A, B and C, D cover the range in composition of types II and I FIs, respectively. The stippled area represents the fluid regime during the formation of the gold mineralization at the $\mathrm{FB}$ mine. A limit of $400^{\circ}-500^{\circ} \mathrm{C}$ is given by the chlorite and arsenopyrite geothermometers. The area filled with thin lines represents the $P-T$ regime related to the thrust of the Barrocas Dome over the $F B$ Mine during mineralization. (b) P-T regimes for the FMP, MR, and FC gold deposits estimated using bulk density isochores, arsenopyrite and chlorite geothermometers and mineral paragenesis. Curve 1 marks the first appearance of biotite (Nitsch 1970). Bulk-density isochores (thick lines) A and $B$ for the FMP and MR deposits, and $C$ and $D$ for the FC deposit, cover the range in composition of type-II FIs in populations where they show relatively constant degree of fill. Isochores represented by thin lines constrain the range of $\mathrm{CO}_{2}$ density of type-I FIs in the FMP deposit. The areas filled with thin lines represent the estimated $P-T$ conditions for gold mineralization in the investigated gold deposits. The stippled area represents the total fluid regime imposed from the formation of the gold mineralization to periods of uplift. The numbers on the isochores represent bulk fluid densities in $\mathrm{g} / \mathrm{cm}^{3}$.

inclusion type in most of the gold-bearing quartz veins of these deposits (Table 1), being virtually the only inclusion type in a number of them. At the FMP and MR deposits, these inclusions are composed solely of $\mathrm{CO}_{2}$ and subordinate amounts of $\mathrm{CH}_{4}(0.5-1.4 \mathrm{~mol} \%)$ and/or $\mathrm{N}_{2}(1.1-2.5 \mathrm{~mol} \%)$, whereas at the AMB deposit a higher and more variable concentration of other volatiles are present: $\mathrm{XCH}_{4}=2-4.8$ $\mathrm{mol} \% ; \mathrm{XN}_{2}=1.3-9.6 ; \mathrm{XH}_{2} \mathrm{~S}=0.1-0.5 \mathrm{~mol} \%$ (Xavier et al. 1996).

Aqueous-carbonic inclusions (type II) are, however, the dominant inclusion type in some of the investigated gold-bearing veins of the FMP deposit (Table 1$)$. These inclusions contain low-salinity $(<6$ wt.\% NaCleq.), $\mathrm{H}_{2} \mathrm{O}-\mathrm{CO}_{2}(9.0 \mathrm{~mol} \%$ to $17.5 \mathrm{~mol} \%$ ) fluids, with less than $1 \mathrm{~mol} \%$ of $\mathrm{CH}_{4}$ and $\mathrm{N}_{2}$. Their minimum trapping temperatures are generally difficult to assess, because they invariably decrepitated before total homogenization, between $235^{\circ} \mathrm{C}$ and $340^{\circ} \mathrm{C}$.

The $\mathrm{CO}_{2}$-rich FIs of type I, ubiquitous and abundant in all the investigated gold deposits of the RIGB, provide no evidence that they have been the result of modifications after trapping of an original $\mathrm{H}_{2} \mathrm{O}$ - 


\begin{tabular}{|c|c|c|c|c|c|c|c|c|c|}
\hline Deposits & Fluid Inclusions & $\begin{array}{c}\text { Types and } \\
\text { compositions }\end{array}$ & $\begin{array}{l}\text { Nature of the } \\
\text { inclusions }\end{array}$ & $\underset{\left({ }^{\circ} \mathrm{C}\right)}{\operatorname{TmCO}}$ & $\begin{array}{l}T h_{c} \\
\left({ }^{\circ} \mathrm{C}\right)\end{array}$ & $\begin{array}{c}\mathbf{H}_{\mathbf{c}} \\
\mathrm{g} / \mathrm{cm}^{3}\end{array}$ & $\begin{array}{c}\text { Salinity } \\
\text { wt } \% / \\
\mathrm{NaCleq} \\
.\end{array}$ & $\mathrm{Th}_{1}\left({ }^{\circ} \mathrm{C}\right)$ & $\begin{array}{c}\text { P-T } \\
\text { conditions } \\
\left(\mathrm{kbar} /{ }^{\circ} \mathrm{C}\right)\end{array}$ \\
\hline \multicolumn{10}{|c|}{ Gold loposits in the Southern Scetor } \\
\hline \multirow[b]{2}{*}{ FH } & Monophass cirbonic & $\underset{\mathrm{CO}_{2} \pm \mathrm{CI}_{4} \pm \mathrm{N}_{2}}{\mathrm{I}}$ & $\begin{array}{l}\text { Primary to visin } \\
\text { formation and } \\
\text { recrystallization }\end{array}$ & $-61,6 /-56.6$ & $\begin{array}{l}-11 \text { I } \\
22 \\
\text { (L) }\end{array}$ & $\begin{array}{l}0,93 / \\
0,6\end{array}$ & - & - & $\begin{array}{l}1.8-3.51 \\
4001-500\end{array}$ \\
\hline & aquecous-carlwanic & $\begin{array}{c}\text { II } \\
\mathrm{H}_{2} \mathrm{O}+\mathrm{CO}_{2} \\
+\mathrm{CH}_{\dot{2}}+\mathrm{N}_{2}\end{array}$ & $\begin{array}{l}\text { 3rimary to } \\
\text { recrystallization }\end{array}$ & $-60.61-56.6$ & $\begin{array}{c}111 \\
18,0 \\
(\mathrm{~L})\end{array}$ & $\begin{array}{l}0,4 / \\
0,93\end{array}$ & $1.6-3.5$ & $160-240$ & $\begin{array}{l}4.5-6.51 \\
400-50 i j\end{array}$ \\
\hline \multirow[b]{2}{*}{ FC } & Monophase carbonic & $\stackrel{\mathrm{I}}{\mathrm{CO}_{2} \perp \mathrm{CH}_{1} \perp \mathrm{N}_{2}}$ & $\begin{array}{l}\text { Primary to vein } \\
\text { formation and } \\
\text { recrystallization }\end{array}$ & $-57.7 /-57.3$ & $\begin{array}{l}11.5 / 25 \\
(\mathrm{~L})\end{array}$ & $\begin{array}{l}0.41 / \\
0.64\end{array}$ & - & - & nd \\
\hline & Aqueous-carbonic & $\begin{array}{c}\text { II } \\
\mathrm{H}_{2} \mathrm{O}+\mathrm{CO}_{2} \\
+\mathrm{CH}_{2}+\mathrm{N}_{2}\end{array}$ & $\begin{array}{l}\text { Trimary to vecin } \\
\text { formation and } \\
\text { recrystallization }\end{array}$ & $-57.6 /-57.2$ & $\begin{array}{l}18 / 27 \\
(\mathrm{~L})\end{array}$ & $\begin{array}{l}0.72 / \\
0.76\end{array}$ & $3.3 / 4.8$ & nd & $\begin{array}{c}280-422 \\
1-3.5\end{array}$ \\
\hline \multicolumn{10}{|c|}{ Gold Deposits in the Northern Sector } \\
\hline \multirow[b]{2}{*}{ FMP } & Monophase carbonic & $\stackrel{\text { I }}{\mathrm{CO}_{2} \perp \mathrm{CH}_{4} \perp \mathrm{N}_{2}}$ & $\begin{array}{l}\text { Primary and } \\
\text { late to vcin } \\
\text { formation }\end{array}$ & $-58 /-57.8$ & $\begin{array}{c}-25 / 30 \\
(\mathrm{~L})\end{array}$ & $1.05 / 0.61$ & - & - & \multirow[b]{2}{*}{$\begin{array}{l}2.1-4.4 \\
320-420 \\
\text { immiscibility }\end{array}$} \\
\hline & (Dominant) or & $\begin{array}{c}\text { II } \\
\mathrm{H}_{2} \mathrm{C}+\mathrm{CO}_{2} \\
+\mathrm{CH}_{2}+\mathrm{N}_{2}\end{array}$ & $\begin{array}{l}\text { Primiry to } \\
\text { vain formation }\end{array}$ & $-56.8 /-56.5$ & $\begin{array}{c}23 / 27 \\
(\mathrm{~L})\end{array}$ & $\begin{array}{c}0.76 / 0.7 \\
3\end{array}$ & $0 / 6$ & nd & \\
\hline MR & $\begin{array}{c}\text { Monophase carbonic } \\
\text { (5) }\end{array}$ & $\underset{\mathrm{CO}_{2} \pm \mathrm{CII}_{4} \pm \mathrm{N}_{2}}{\mathrm{I}}$ & $\begin{array}{l}\text { Primary to } \\
\text { vein form }\end{array}$ & $-57.9 /-56.6$ & $\begin{array}{c}-24.4 / \\
24.0 \\
(\mathrm{~L})\end{array}$ & $\begin{array}{l}1.05 / \\
0.73\end{array}$ & - & - & $\begin{array}{l}\text { nd, but } \\
\text { similat to } \\
\text { li.MP }\end{array}$ \\
\hline AMB & $\begin{array}{c}\text { Monnphase carlonnic } \\
\text { (n) }\end{array}$ & $\begin{array}{c}\mathbf{I} \\
\mathrm{CO}_{2} \pm \mathrm{CH}_{4} \\
\pm \mathrm{N}_{2} \pm \mathrm{II}_{2} \mathrm{~S}\end{array}$ & $\begin{array}{l}\text { Primary to vein } \\
\text { formation antil } \\
\text { rectystallizialion }\end{array}$ & $-59.1 /-58.4$ & $-4 / 22$ & $\begin{array}{l}0.05 / \\
0.75\end{array}$ & - & - & $\begin{array}{c}\mathrm{P}^{\mathrm{n}} \text { nd } \\
\mathrm{T}>500^{\mathrm{n}} \mathrm{C}\end{array}$ \\
\hline
\end{tabular}

Table 1-Main types of fluid inclusions defined in the gold deposits of the southern and northern sectors of the RIGB, with a summary of their microthermometry data and P-T conditions, estimated by independent geothermometers and fluid inclusion isochores. TmCO $\mathrm{O}_{2}=\mathrm{CO}_{2}$ melting temperature; Th ${ }_{c}=$ homogenization of the carbonic phase ( $L=$ liquid state; $V=$ vapor state); $d_{c}=$ density of the carbonic phase; $h_{c}=$ total homogenization. Primary to late recrystallization carbonic and aqueous carbonic $\mathrm{CH}_{4} \pm N_{2}$ inclusions and late stage aqueous inclusions have not been included in the table. nd= not determined.

$\mathrm{CO}_{2}$ fluid (e.g. $\mathrm{H}_{2} \mathrm{O}$ leakage by decrepitation, plastic deformation or diffusion).

FLUID REGIMES, POSSIBLE SOURCES, AND P-T ESTIMATES The $\mathrm{CO}_{2} \pm \mathrm{CH}_{4} \pm \mathrm{N}_{2}$ (type I) and the $\mathrm{H}_{2} \mathrm{O}-\mathrm{CO}_{2} \pm$ $\mathrm{CH}_{4} \pm \mathrm{N}_{2}$ (type II) inclusion fluids are considered as representatives of fluid regimes active during vein formation and the gold mineralizing events in the southern and northern sectors of the RIGB. The $\mathrm{CO}_{2}$-rich fluid, in particular, is unusual for an environment of mesothermal lodegold deposit formation, such as that of the investigated deposits. Such an atypical $\mathrm{CO}_{2}$-rich fluid could, for instance, be the result of (1) extensive $\mathrm{H}_{2} \mathrm{O}$ loss of a previously immiscible $\mathrm{H}_{2} \mathrm{O}-\mathrm{CO}_{2}$ fluid, under a variable pressure regime, during progressive hydration reactions in the host rocks and/or (2) $\mathrm{CO}_{2}$ enrichment, due to its interaction with carbonaceous matter, via the reaction $2 \mathrm{C}+2 \mathrm{H}_{2} \mathrm{O}=\mathrm{CO}_{2}+\mathrm{CH}_{4}$. The latter mechanism may have been particularly important at the $\mathrm{FB}$ Mine, since the fluids show variable $\mathrm{CO}_{2} / \mathrm{CH}_{4}$ ratios, but less likely in the other gold deposits.

Collectively, these fluid regimes are interpreted as part of a deep metamorphic-magmatic hydrothermal system. In this context, the fluid components may have been derived by devolatilization reactions during regional metamorphism and/or from mantle-magmatic sources (e.g. $\left.\mathrm{CO}_{2}, \mathrm{H}_{2} \mathrm{~S}\right)$. These fluid reservoirs have been invoked due to the following evidence: (1) available geochronological data indicate that the gold mineralizing process is related to the latest stages of the felsic magmatism and regional metamorphism of the RIGB, during a collisional geodynamic regime in the Paleoproterozoic (Mello et al. 2000); (2) the occurrence of lamprophyre dikes at the FMP deposit 
attests that the host shear zones may have extended to the mantle crust interface; (3) the $\delta^{18} \mathrm{O}$ and dD composition of the vein quartz and white mica/chlorite in altered wallrocks is consistent with derivation of the $\mathrm{H}_{2} \mathrm{O}$ component of the ore fluids from a deep crustal reservoir $\left(\delta^{18} \mathrm{OH}_{2} \mathrm{O}=6\right.$ to $12^{\mathrm{o}} \%, \delta \mathrm{DH} \mathrm{O}=-16$ to $-55 \%$ for the FB Mine; $\delta^{18} \mathrm{OH}_{2} \mathrm{O}=8$ to $13.5 \%, \delta \mathrm{D}_{2} \mathrm{O}=-7.5$ to $-40 \%$ for the FMP deposit), perhaps during metamorphism and melting at deeper levels associated with periods of magma genesis (Xavier 1991, Xavier et al. 1994, Taylor and Xavier 1996, Xavier, unpubl. data); (4) the $\delta^{13} \mathrm{C}$ compositions of $\mathrm{CO}_{2}$ extracted from inclusion fluids $(-6.0 \%$ o to $10.2 \%$ o overlap the lower range for magmatic $\mathrm{CO}_{2}(-2.5 \%$ o to $-8.2 \%$ o $)$ and mantle $\mathrm{CO}_{2}(-3.0 \%$ o to $-8.0 \%$ o $)$ and point to these two sources as the major carbon reservoirs for the hydrothermal fluids (Xavier 1991 , Xavier et al. 1994); (5) mean $\delta^{34} \mathrm{~S}$ values at 0.6 and $2.5 \%$ obtained for gold-related sulfides, respectively at FB and FMP, point to an important magmatic-derived source for the sulfur in the fluid (Xavier et al. 1994).

The fluid regime dominated by low-temperature $\left(<150^{\circ} \mathrm{C}\right)$, lowsalinity ( $<15 \mathrm{wt} \%$ NaCleq.), late aqueous solutions, possibly of meteoric origin, was also present, but only during uplift of the greenstone sequence.

The P-T conditions of the $\mathrm{CO}_{2}$-rich and the $\mathrm{H}_{2} \mathrm{O}-\mathrm{CO}_{2}$ fluids involved in the gold mineralizing events in the deposits of the southern and northern sectors of the RIGB are depicted in Figure 2. They were constrained based on the hydrothermal alteration assemblage, chlorite and arsenopyrite geothermometers, and the bulk-density isochores for such fluids.
CONCLUSIONS The shear-zone-hosted gold deposits of the RIGB are mainly formed by shear veins hosted in iron-rich mafic rocks, carbonaceous volcaniclastic rocks, carbonaceous turbidites, and quartz-ankerite breccias.

On the basis of fluid inclusion studies in samples of mineralized veins, two main types of ore fluids are defined: a $\mathrm{CO}_{2} \pm\left(\mathrm{CH}_{4}+\mathrm{N}_{2}\right)$ fluid represented by monophase carbonic inclusions (type I), and a low salinity (<6 wt. \% eq. $\mathrm{NaCl}) \mathrm{H}_{2} \mathrm{O}-\mathrm{CO}_{2}-\left( \pm \mathrm{CH}_{4} \pm \mathrm{N}_{2}\right.$ ) fluid, represented by $\mathrm{H}_{2} \mathrm{O}-\mathrm{CO}$ fluid inclusions (type II). These fluids were directly channeled into favorable structural sites (i.e. shear-zones) and are interpreted as part of a deep hydrothermal system, in which devolatilization reactions during the regional metamorphism, as well as mantle-magmatic sources, contributed with fluid components. Whether the $\mathrm{H}_{2} \mathrm{O}$-depleted, $\mathrm{CO}_{2}$-rich fluid constituted an original fluid regime, atypical in mesothermal lode-gold deposits, or it was the result of modifications of a previous $\mathrm{H}_{2} \mathrm{O}-\mathrm{CO}_{2}$ fluid, still remains an open question. The fluid regimes were active at different crustal levels at temperatures varying from 280 up to $500^{\circ} \mathrm{C}$, and pressures varying from 1 up to $4.4 \mathrm{~kb}$, under which the gold mineralization took place in the several deposits investigated in the southern and northern sectors of the RIGB. Pressures may have attained values up to $6.5 \mathrm{~kb}$ at FB, in the southern sector, during thrusting of the Barrocas Dome.

Gold deposition from bisulfide complexes was probably closely linked with and dependent upon redox changes that accompanied the interaction of the fluids with mafic and carbonaceous host rocks.

Acknowledgements To two anonymous referees of RBG for the critical review of the manuscript.

\section{References}

Alves da Silva F.C., Chauvet A., Faure M. 1993. Early-Proterozoic orogeny (Transamazonian) and syntectonic granite emplacement in the Rio Itapicur greenstone belt, Bahia-Brazil. C.R. Acad. Sci. Paris, t.316, Série II:1139-1146.

Barrueto H.R. 1996. Intrusões sub-vulcânicas alcalinas e lamprófiros nas mineralizaçõe auríferas do greenstone belt do Rio Itapicuru, Bahia: petrografia, geoquímica e inclusões fluidas. IG/UNICAMP, unpub. M.Sc. Dissertation, 160p.

Coelho C.E.S. 1994. Genèse des Fluides dans les Zones Deformées et Mineralisées en Or de la Ceinture de Roches Vertes de Rio Itapicuru (Brésil): Gisements de Fazenda Brasileiro et Fazenda Maria Preta. Une Reconstitution basée sur l'étude des inclusions fluides dans leur contexte microstructural. Université d'Orléans, France, Ph.D. Thesis, 330p.

Kishida A. \& Riccio L. 1980. Chemostratigraphy of lava sequences from the Rio Itapicuru greenstone belt, Bahia, Brazil. Precamb Research, 11:161-178

Marimon M.P.C, Kishida A., Teixeira J.B.G. 1986. Estudo da alteração hidrotermal relacionada à mineralização aurífera na mina Fazenda Brasileiro (BA). In SBG, Congr. Bras. Geol., 34, Goiânia (GO), Anais, 4:1556-1570.

Mello E.F., Xavier R.P., Tassinari C.C.G., McNaughton N.J., Fletcher I., Hagemann S. Lacerda C.M.M, Oliveira E.P. 2000. Age constraints of felsic intrusions, metamorphism, deformation and gold mineralization in the paleoproterozoic Rio Itapicuru greenstone belt, NE Bahia State, Brazil. $31^{\text {st }}$ International Geological Congress, Rio de Janeiro, Brazil (in press).

Nitsch K.H. 1970. Experimental determination of the upper stability of stilpnomelane. Fortschr. Mineral. 47:48-49.

Pereira Silva G.L. 1998. A associação ouro-matéria carbonácea e implicações na gênese de mineralizações auríferas filoneanas. IG/UNICAMP, unpub. M.Sc. Dissertation, $97 \mathrm{p}$

Pires P.F.R. 1996. Caracterização tectono-metamórfica do depósito aurífero Ambrósio greenstone belt do Rio Itapicuru - Bahia. IG/UNICAMP, unpub. M.Sc. Dissertation, $95 \mathrm{p}$
Silva M.G. 1987. Geochemie, petrologie and geotektonische entwicklung eines Proterozoischen greunsteingnertels, Rio Itapicuru, Bahia, Brasilien. University of Freiburg, Freiburg, Germany, Ph.D. Thesis, $141 \mathrm{p}$.

Taylor B.E. \& Xavier, R.P. 1996. Primary and secondary fluids in mesothermal lode gold deposits: comparison of Mesozoic N. American and L.. Proterozoic brazilian deposits. In: SBG, Congr. Bras. Geol., 39, Salvador, Bahia, Anais, 7:342-346.

Teixeira J.B.G., Kishida A., Marimon M.P.C., Xavier R.P., McReath I. 1990. The Fazenda Brasileiro gold deposit, Bahia: Geology, hydrothermal alteration, and fluid inclusion studies. Econ. Geol., 85:990-1009.

Vieira M.B.H., Lobato L.M., Assis C.M., Gomes F.C.A., Silva R.A., Nascimento H.S., Orlandi P.H. 1998. Contribuição ao estudo da alteração hidrotermal na Mina de Ouro de Fazenda Brasileiro, Bahia. In: SBG, Congr Bras. Geol, 40, Belo Horizonte, Anais, p. 130

Xavier R.P. 1991. The role of microstructural and fluid processes in the genesis of gold bearing shear zones: Fazenda Maria Preta mine, Rio Itapicuru greenstone belt Bahia, Brazil. University of Southampton, UK, Ph.D. Thesis, 241p.

Xavier R.P., Foster R.P., Fallick A.E., Alderton D.H.M., 1994. Potential fluid reservoirs for mesothermal gold deposit in the Rio Itapicuru greenstone belt, Bahia, Brazil. Comunicaciones $\mathbf{4 5}: 13-22$

Xavier R.P., Barrueto H.R., Pires P.F.R., Batista J.J. 1996. CO -dominated fluids in greenschist and amphibolite facies mesothermal lode-gold deposits, Rio Itapicuru greenstone belt, NE Bahia. In: SBG, Congr. Bras. Geol., 39, Salvador, Bahia, Anais, 7:486-489

Contribution IGC-040

Received January 28, 2000

Accepted for publication May 10, 2000 